\title{
Oro-dental and Radiographic Findings of Weyers Acrofacial Dysostosis: Report of a Rare Case
}

\section{Weyers Akrofasiyal Disostozis'in Ağız-diş ve Radyografik Bulguları: Nadir Bir Olgu Sunumu}

\author{
(D) Esra ÖZ, iD Zuhal KIRZIOĞLU
}

Süleyman Demirel University Faculty of Dentistry, Department of Pedodontics, Isparta, Turkey

\begin{abstract}
Weyers acrofacial dysostosis is a rare type of ectodermal dysplasia syndrome characterized by mild short stature, postaxial polydactyly, dystrophic nails, and dental anomalies (hypodontia, microdontia, taurodontism). In this case report, we present the oral and radiographic findings of a 7-year-old girl consistent with the diagnosis of Weyers acrofacial dysostosis. Through this detailed discussion, we aim to contribute to the literature.
\end{abstract}

Keywords: Oral findings, polydactyly, syndrome, Weyers acrofacial dysostosis

\section{ÖZ}

Hafif boy kısalığı, postaksiyal polidaktili, distrofik tırnaklar ve dental anomaliler (hipodonti, mikrodonti, taurodontizm) ile karakterize otozomal dominant bir bozukluk olan Weyers akrofasiyal disostozis, ektodermal displazi sendromunun nadir görülen bir tipidir. Bu olgu raporunda, 7 yaşındaki kız çocuğunun Weyers akrofasiyal disostozis tanısı ile örtüşen oral ve radyografik bulguları sunulmuştur. $\mathrm{Bu}$ ayrıntılı tartışma sayesinde literatüre katkıda bulunmak amaçlanmıştır.

Anahtar Sözcükler: Ağız bulguları, polidaktili, sendrom, Weyers akrofasiyal disostozis

\section{Introduction}

Ectodermal dysplasia is a well-known hereditary disorder associated with the abnormal development of structures such as teeth, nails, hair, nerve cells, and sweat glands (1). Weyers acrofacial dysostosis (WAD) is a rare type of ectodermal dysplasia syndrome characterized by mild short stature, postaxial polydactyly, dystrophic nails, and dental anomalies (2). It has been reported to be caused by heterozygous mutation in the $E V C 2$ and $E V C$ genes located on chromosome 4p16.2 (3).

Many phenotypic features of WAD are similar to Ellis-van Creveld (EVC) syndrome, an autosomal recessive disorder. However, WAD is a milder condition compared to EVC and does not include features such as short ribs, thoracic dysplasia, and congenital heart disease, which are commonly observed in patients with EVC (4).

In this case report, we present the oral and radiographic findings of a 7-year-old girl consistent with the diagnosis of WAD. In the limited number of accessible reports of WAD, oro-dental findings have rarely been encountered. Through this detailed discussion, we aim to contribute to the existing literature.

\section{Case Report}

A 7-year-old girl was brought to our clinic by her parents for a dental examination. Her history revealed no consanguinity between the mother, father and the first of the two daughters of the family. The patient showed normal growth with a height of 122 
$\mathrm{cm}$, a weight of $26 \mathrm{~kg}$ and no mental retardation. It was observed that the patient had a straight face profile with a marked lower jaw sulcus and dystrophic changes in the hands and toenails. The patient's parent stated that she had one more fingers on both hands and feet at birth, and underwent surgical correction at 9 months of age. Upon questioning, we learned that there was a family history of polydactyly at birth in the hands and feet of the patient's mother, grandfather, as well as her 3-year-old sister, who underwent surgery at 8 months of age.

During the intraoral examination, we observed multiple wide labial frenula and a unilateral posterior crossbite. The saliva flow rate was measured to be $1 \mathrm{~mL} / \mathrm{min}$ with a $\mathrm{pH}$ value of 6 . The patient had microdontia with cone-shaped primary incisors and primary molars with atypical cusps. The newly erupting upper incisors, however, were abnormally large with talon cusps. The patient had wide diastemas between the teeth as well as gingival recession in the vestibule in association with the primary canines. Radiographic evaluation showed congenitally missing teeth (permanent mandibular right and left central, right lateral),

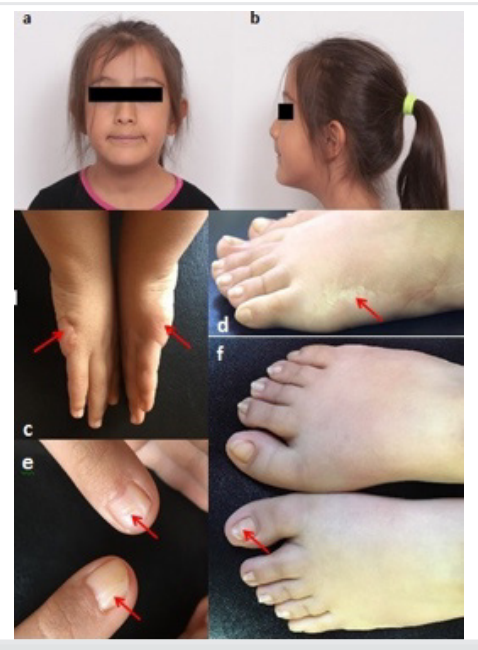

Figure 1. Facial appearance a) Frontal view, b) lateral profile, c, d) Bilateral postaxial polydactyly were removed at birth by surgical operations on both hands and feet, only scars (red arrows) were seen, e, f) Dystrophic hands and toenails

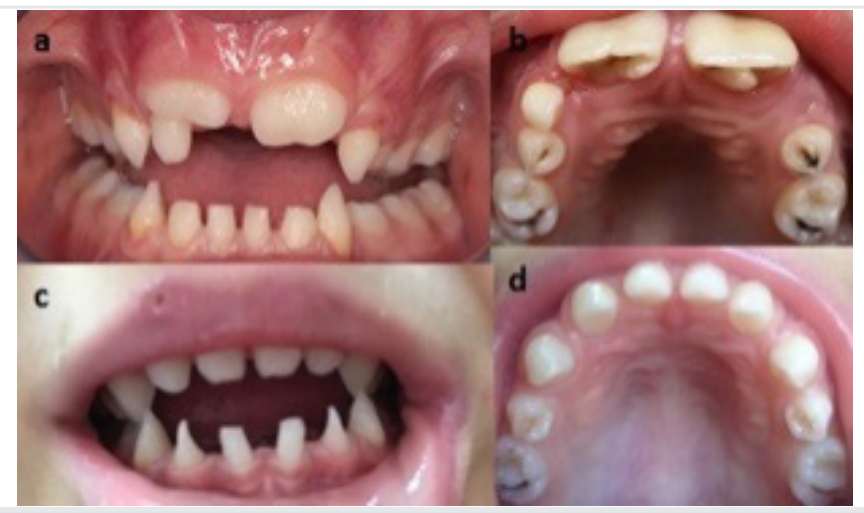

Figure 2. a, b) Intra-oral examination of the patient and (c, d) her sibling taurodontism (permanent mandibular and maxillary first molars), and changes in the direction of tooth germs (permanent mandibular right and left second premolars).

The patient's 3-year-old sibling had an open bite due to the continued use of a pacifier. She also displayed microdontia with cone-shaped primary incisors and primary molars with atypical cusps, large diastemas between the teeth, similar to the patient.

Clinical and radiographic examination of the father showed no oral findings similar to the daughters. Although the patient's mother was found to have a history of polydactyly, she refused our invitation to visit the clinic for clinical examination and did not consent to genetic diagnostic testing.

Dental treatment planning was done and the patients were provided with all the necessary information. The importance of oral care and regular check-ups for maintaining oral health was explained to the patient.

\section{Discussion}

Many disorders that require special attention in childhood are described in the literature. One such syndrome is WAD, a rare type of ectodermal dysplasia characterized by polydactyly, dystrophic nails, and dental anomalies. Patients with WAD have been reported to have a normal facial appearance, short stature, dysplastic finger and toenails separated by thick vertical lines, and the presence of extra digits in the feet and hands (2,4-7). Although there was no growth retardation in our patient, the other findings were observed. Family history revealed polydactyly at birth in the hands and feet of the patient's mother, grandfather, and sister.

WAD is usually characterized by dental findings including multiple labial hyperplastic frenula, hypodontia, microdontia, taurodontism, conical teeth, and enamel hypoplasia (2). The patient displayed all these dental findings except enamel hypoplasia, suggesting a diagnosis of WAD.

The differential diagnosis for WAD includes EVC, Witkop and Orofacial Digital syndromes.

It has previously been reported that cardiac malformations occur in approximately $50-60 \%$ of patients with EVC with

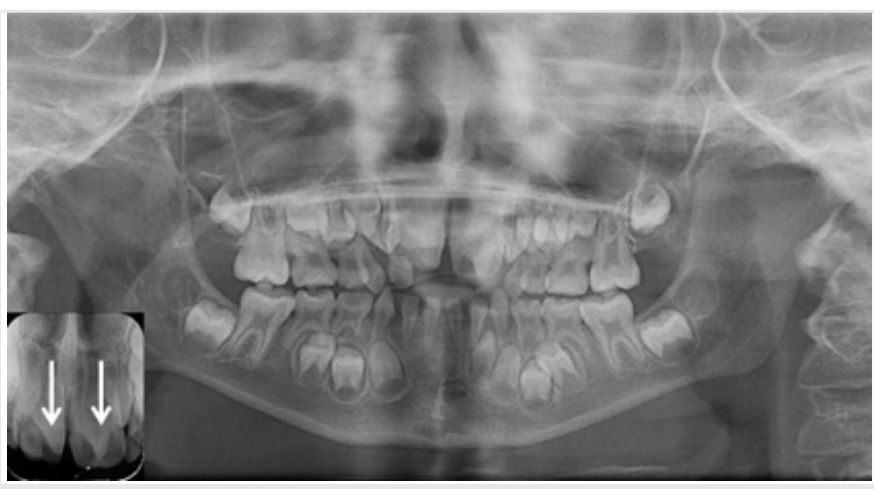

Figure 3. The panoramic radiograph of the patient and periapical film showing the talon cusps 
characteristic features of short ribs, thoracic dysplasia, and acromesomelic dwarfism (4). Our patient did not show these characteristic features and there was also no cardiac disturbance. The patient also showed polydactyly, a characteristic of WAD patients. It has previously been reported that polydactyly occurs commonly in the hands of EVC patients but occurs in the feet of only $10 \%$ of patients with EVC (4). Oral findings such as multiple hyperplastic frenula, diastemas, taurodontism, and hypodontia (mandibular and maxillary anterior region) observed in our patient are also observed in patients with EVC (8). However, natal and supernumerary teeth are seen in $25-30 \%$ of patients with EVC (8) and were not observed in our patient.

Although hypodontia and nail dysplasia, which are known to be characteristic features of Witkop syndrome (9) are seen in our patient, the presence of supernumerary digits helps to differentiate WAD from Witkop syndrome.

Orofacial digital syndrome (OFDS1) is a developmental genetic disorder frequently seen in girls with $\mathrm{X}$ dependent dominant transition and characterized by malformation of the oral cavity, face, and fingers (10). While our patient had multiple hyperplastic frenula, a finding commonly seen in OFDS1 patients, she did not show other features characteristic of OFDS1, including the lack of development, hypoplasia of the nasal limbs, mental disability, and polycystic kidney disease. Another distinguishing feature was the presence of dystrophic nails, a finding not observed in patients with OFDS1.

Due to the presence of dental anomalies (hypodontia, taurodontism, macrodont incisors) in the patient, it was explained that the protective and preventive treatments (fluoride and fissure sealant applications, dietary control), oral hygiene procedures, regular dental follow-up were important and necessary dental treatments were performed. It has been stated that there should be periodic follow-up of the teeth due to the changes in the direction of tooth germs. Since there were no parental and patient complaints due to the size and appearance of the anterior teeth, the model analysis was performed, and then necessary tooth interproximal strippings were done.

Although genetic analysis would provide a definitive diagnosis of WAD, the patient's mother did not give consent for genetic testing. The diagnosis of WAD in our patient was supported by family history as well as oral and radiographic findings.

\section{Ethics}

Informed Consent: Consent was obtained from the parents of the patient.
Peer-review: Externally peer-reviewed.

\section{Authorship Contributions}

Concept: Z.K., E.Ö., Design: Z.K., E.Ö., Data Collection or Processing: Z.K., E.Ö., Analysis or Interpretation: Z.K., E.Ö., Literature Search: E.Ö., Writing: Z.K., E.Ö.

Conflict of Interest: No conflict of interest was declared by the authors.

Financial Disclosure: The authors declared that this study received no financial support.

\section{References}

1. Itthagarun A, King NM. Ectodermal dysplasia: A review and case report. Quintessance Int 1997;28:595-602.

2. Weyers H. A correlated abnormality of the mandible and extremities (dysostosis acrofacialis). Fortschr Geb Rontgenstr 1952;77:562-7.

3. Howard TD, Guttmacher AE, Mckinnon W, Sharma M, Mckusick VA, Jabs EW. Autosomal dominant postaxial polydactyly, nail dystrophy, and dental abnormalities map to chromosome 4p16, in the region containing the Ellis-van Creveld syndrome locus. Am J Hum Genet 1997;61:1405-12.

4. Shetty DC, Singh HP, Kumar P, Verma C. Report of Two Siblings with Overlapping Features of Ellis-van Creveld and Weyers Acrodental Dysostosis. J Clin Imaging Sci 2012;2:18.

5. Roubicek M, Spranger J. Weyers acrodental dysostosis in a family. Clin Genet 1984;26:587-90.

6. Ruiz-Perez VL, Goodship JA. Ellis-van Creveld syndrome and Weyers acrodental dysostosis are caused by cilia-mediated diminished response to hedgehog ligands. Am J Med Genet Part C Semin Med Genet 2009;151:341-51.

7. Goswami S. Weyers acrofacial dysostosis (Curry-Hall Syndrome): Report of a rare case. Arch Med Health Sci 2018;6:143-6.

8. Tuna EB, Koruyucu M, Kürklü E, Çifter M, Gençay K, Seymen F, et al. Oral and craniofacial manifestations of Ellis-van Creveld syndrome: Case series. J Craniomaxillofac Surg 2016;44:919-24.

9. Hudson CD, Witkop CJ. Autosomal dominant hypodontia with nail dysgenesis. Report of twenty-nine cases in six families. Oral Surg Oral Med Oral Pathol 1975;39:409-23.

10. 10.Toriello HV, Franco B. Oral-facial-digital syndrome Type I. In: Pagon RA, Bird TC, Dolan CR, Stephens K, editors. GeneReviews. Seattle: University of Washington; 1993; July 24,2002 (updated March 9, 2007). Available at: http://www.ncbi.nlm.nih.gov/ books/ NBK1188/. 